\title{
Separation of Flavonoids and the Evaluation of the Anti-inflammatory Potential of Flavonoid-enriched Extracts from the Thlaspi arvense Linn by Inhibiting the Activation of TLR-4/NF-K B
}

\section{Xiang Wang \\ Guangxi University \\ Panke Zeng \\ GuangXi University \\ Xuejiao Li \\ GuangXi University \\ Liyuan Cheng \\ Guangxi University \\ Haroon Rashidb}

Federal University of Mato Grosso do Sul: Universidade Federal de Mato Grosso do Sul

Hong Liu

Guangxi University

Xu Liu

Guangxi University

Lisheng Wang ( $\nabla$ w_lsheng@163.com )

Medical College of Guangxi University

\section{Research}

Keywords: Thlaspi arvense Linn ,Flavonoids, Lipopolysaccharide, Anti-inflammatory effects, NF-k B

Posted Date: September 21st, 2021

DOI: https://doi.org/10.21203/rs.3.rs-895681/v1

License: (c) (i) This work is licensed under a Creative Commons Attribution 4.0 International License. Read Full License 


\section{Abstract}

Background: Thlaspi arvense Linn, belonging to the dicotyledonous cruciferous family, is distributed Europe and Asia. In this study, we evaluated for the first time the anti-inflammatory effects of Thlaspi arvense Linn on LPS-stimulated RAW264.7 macrophages, and explored the related mechanism.

Methods: The extract was identified and quantified using the HPLC, NMR. The anti-inflammatory activities of crude extracts $\mathrm{C} 11, \mathrm{C} 12, \mathrm{C} 13$ were screened by xylene-induced ear swelling and carrageenaninduced foot swelling in mice. The inflammatory mediators, pro-inflammatory cytokines and TLR-4mediated signals in LPS-stimulated RAW264.7 macrophages were determined using NO activity assay, MTS, ELISA and Western blot.

Results:The extract of Thlaspi arvense Linn was found to enrich flavonoid囚mainly Orientin,Isoorientin,Vitexin;ISovitexin,Luteolin-7-O- $\beta$-D-glucoside,Apigenin-7-O- $\beta$-Dglucoside,Luteolin,Apigeni囚.5,7-dihydroxy-flavone-4'-(6"- $\beta$-0-glucopyranoside)- $\beta$-0-D-glucopyranoside was novel, whereas isosapogenin and 8-methoxyvitexin were isolated for the first time from Thlaspi arvense Linn. The extract (flavonoid-enriched) inhibited xylene-induced ear swelling and carrageenan-induced foot swelling in mice. And suppressed LPS-induced overrelease of iNOS,TNF-a,COX-2 and IL-6 in RAW264.7 macrophages. The extract inhibited the inflammatory response through the signaling pathway mediated by TLR-4/NF- kappa B pathway and its downstream signals, IKB-a, NF-KB-P65 and IL-1 $\beta$ in LPSstimulated macrophages.

Conclusions: The present results demonstrate that the extract of Thlaspi arvense Linn inhibit inflammatory responses via the TLR-4/NF-KB-mediated signaling pathway.

\section{Background}

Inflammation is a specific, self-controlled immune response. However, inflammation sometimes produces unbalanced responses, leading to chronic systemic damage and inflammatory disorders [1, 2], further causing cardiovascular disease, rheumatism, and cancer $[3,4]$.Many important studies have analyzed its potential benefits to human health. It is well known that macrophages play a key role in inflammatory responses[5]. Under infectious and non-infectious stimulation, overactivated macrophages initiate inflammatory responses by releasing inflammatory mediators and pro-inflammatory cytokines. Our group used the RAW264.7 of macrophages stimulated by lipopolysaccharide (LPS) as a model to observe the anti-inflammatory activity and the effects of cyclooxygenase-2 (COX-2), inducible nitric oxide synthase (iNOS), and interleukin-6 (IL-6). At the same time, after lipopolysaccharide activates TLR-4, it subsequently activates its downstream signals, including MyD88/NF-k B [6, 7].

Thlaspi arvense Linn also referred to as Kugai is the whole herb of the dicotyledonous cruciferous family, which grows in Asia and Europe. Its above-ground parts including the whole herb, tender seedlings, and seeds can be used in medicine, having the effects of heat-clearance, detoxification, diuresis, and detumescence. It is frequently used for the treatment of glomerulonephritis, gastritis, and rheumatoid 
arthritis. Thlaspi arvense Linn is a a well-known Chinese herbal medicine with flavonoids as its main chemical components $[8,9]$. This plant is applied in traditional medicine in many countries. Feng et al. used mouse writhing method and hot plate method to observe the effects of Thlaspi arvense Linn on mouse capillary permeability and xylene-induced auricle swelling in mice, which verified the antiinflammatory effect of Thlaspi arvense Linn[10]. The herb is recorded in the Pharmacopoeia of the people's Republic of China (State Pharmacopoeia Committee. 2010 edition). Shisanwei Thlaspi Capsule is a product of this traditional Chinese medicinal extract and has been approved by the National Medical Products Administration (NMPA) for the treatment of cystitis and rheumatoid arthritis (No: Z20003052). Besides, Huahong tablet containing the ingredient of Thlaspi arvense Linn has the effect of clearing away heat and detoxification (No: Z45020922).

We studied the effects of Thlaspi arvense Linn extract on NF-K B signal transduction pathway. The Thlaspi arvense Linn extract can inhibit the release of tumor necrosis factor- $a$ in macrophages, the phosphorylation of downstream effector factors I k B-a and NF-k B p65, reduce the expression of interleukin-1 $\beta$ (1L-1 $\beta$ ), and block the activation of NF-K B induced by lipopolysaccharide (LPS). Therefore, we speculated that Thlaspi arvense Linn extract may exert its anti-inflammatory effect through NF-K B mediated signal pathway.

\section{Materials And Methods}

\subsection{Chemicals and reagents}

UV-2100 spectrometer (Beijing Rayleigh Analytical Instrument Co., Ltd., P.R. China); macroporous resin (D101; Tianjin kwangfu Fine Chemical Co., P.R. China); Prep. HPLC: UC-3282 type semi-preparative HPLC (Beijing Photoelectric Technology Co., Ltd., P.R. China), Welchrom C18 column ( $5 \mu \mathrm{m}, 10 \times 250 \mathrm{~mm})$, flow rate $3 \mathrm{ml} \mathrm{min-1;} \mathrm{detection,} \mathrm{at} 273 \mathrm{~nm}$. HPLC: Agilent 1200 HPLC system (Agilent Technologies Co. Ltd. P.R.

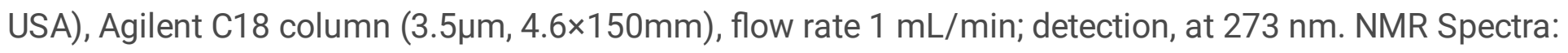
Bruker ARX-600 spectrometer; in DMSO-d6; סin ppm rel. to Me4Si as an internal standard: $J$ in Hz. HR-ESIMS: Waters API QSTAR Pular-1 mass spectrometer; in $\mathrm{m} / \mathrm{z}$. Plant Material. Aerial parts of pennycress (Thlaspi arvense Linn.) were obtained from Huahong Pharmaceutical Limited by Share Ltd, Guangxi Zhuang Autonomous Region, P. R. China. The plant was identified by traditional Chinese medicine pharmacist Bin Dai, Guangxi Institute of Minority Medicine. the plant name has been checked with http://www.theplantlist.org, 53451-3.

\subsection{Extract preparation}

The medicinal materials of Thlaspi arvense Linn were crushed into a coarse powder, and $0.5 \mathrm{~kg}$ of this powder was accurately weighed and placed in a $10 \mathrm{~L}$ round bottom flask. According to the liquid-solid ratio of 10:1, $5 \mathrm{~L}$ deionized water was added to the powder and the mixture was placed in an electric heating jacket for reflux extraction for 3 hours. The extraction temperature was maintained at $100^{\circ} \mathrm{C}$. Upon the completion of extraction, a rotary evaporator was used for decompression and concentration to remove the solvent and obtain aqueous extract. Subsequently, ethanol (65\%) was added to the extract to 
dissolve it. The ethanol extract was then stirred and placed in the refrigerator at $4^{\circ} \mathrm{C}$ for $24 \mathrm{~h}$. It was subsequently filtered to remove the precipitation. The filtrate was subjected to decompression and concentration to obtain the extract. A small amount of anhydrous ethanol was added to dissolve the extract. It was then poured into the evaporating dish, placed in the water bath and heated to dryness. The final crude product was $57.12 \mathrm{~g}(\mathrm{C} 1)$.

\subsection{Separation}

The above crude product, $\mathrm{C} 1$, was dissolved in distilled water $(1000 \mathrm{~mL})$, followed by its extraction with petroleum ether $(5 \times 1000 \mathrm{~mL})$ to remove the nonpolar components(C10). The solution was then extracted with EtOAc and n-BuOH in turn. The product (C1) was separated into a 14.54-g EtOAc fraction (C11, yield: 25.47\%, w/w), a 21.13-g n-BuOH fraction (C12, yield: 36.99\%, w/w), and a 19.46-g water fraction (C13, yield: $34.08 \%, w / w)$.

C12 was dissolved in deionized water. The sample was ultrasonically degassed on the top of D101 macroporous resin column. After 17 hours, deionized water was used for elution to remove the unadsorbed components of macroporous resin and obtain a colorless eluent. D101 macroporous resin column was eluted successively with $10 \%, 30 \%$, and $50 \%$ ethanol aqueous solutions separately until the eluent was colorless. The eluents of $10 \%, 30 \%$, and $50 \%$ ethanol part were collected and concentrated to obtain C120.

Then $20.0 \mathrm{~g} \mathrm{C12}$ was separated into a 3.36-g 10\% ethanol fraction (C122), a 4.18-g 30\% ethanol fraction (C123), a 2.86-g 50\% ethanol fraction (C124) by D101 macroporous resin column.

The $\mathrm{C} 11$ was applied to a silica gel column $\left(25 \times 2 \mathrm{~cm}^{2}\right)$ and gradiently eluted with EtOAc-PE. Fraction EtOAc: PE (1:1) was further purified by elution technique on prep. HPLC using $0.4 \%$ aqueous glacial acetic acid and acetonitrile as eluents to give compounds $10(11 \mathrm{mg})$ and $11(13 \mathrm{mg})$. Preparative HPLC was applied to separate fraction C123 to give compounds 1 (21 mg), 2 (12mg), 3 (8mg), 4 (14mg), 5 (7mg), 6 (21 mg), $7(10 \mathrm{mg})$ and $8(15 \mathrm{mg})$; and fraction C124 to produce compound $9(13 \mathrm{mg})$.

\subsection{Animal}

Special pathogen-free male mice (SPF grade, Kunming race) weighing 18-22g were purchased acclimation for three days, the mice were randomly divided into groups for the experiments (10 mouse/group). The animal experiments were performed as per Principles of Laboratory Animal Care and Use in Research (Ministry of Health, Beijing, China). The protocols for the animal experiments were approved by the Animals Ethics Committee of Guangxi Medical University.

\subsection{Xylene-induced ear edema assay}

The mice in the negative control group were intragastrically administered with deionized water, and those in the treatment groups also received deionized water once a day for five days. The treatments included extracts $\mathrm{C} 1, \mathrm{C} 11, \mathrm{C} 12, \mathrm{C} 13, \mathrm{C} 120$ and dexamethasone acetate. The dosages used were $100 \mathrm{mg} / \mathrm{kg}$ for extracts $\mathrm{C} 1, \mathrm{C} 11, \mathrm{C} 12, \mathrm{C} 13, \mathrm{C} 120$ and $5 \mathrm{mg} / \mathrm{kg}$ for dexamethasone acetate. One hour after the last 
administration, edemas were induced by topical application of $50 \mu \mathrm{L}$ of xylene on both surfaces of each mouse's right ear. After an hour of treatment, the mice were killed by cervical dislocation. A piece of tissue ( $8.0 \mathrm{~mm}$ in diameter) was punched out from both ears of each mouse and weighed. The extent of edema was expressed as the difference in the weight between the earpieces from the same animal $[11,12]$. The anti-inflammatory activity was evaluated as the percentage of the inhibition of edema (PIE), which was calculated by Eq. 1 .

$\mathrm{PIE}=[($ negative mean - treated mean $) /$ negative mean $] \times 100 \%$

\subsection{Carrageenin-induced paw edema assay}

The treatment of the mice and the samples used in this assay were the same as in the xylene-induced ear edema assay. One hour after the last administration, edemas were induced by hypodermic injection of $0.05 \mathrm{~mL}$ carrageenin $(1 \%)$ into the right hind paw of each mouse. After five hours of treatment, the mice were killed by cervical dislocation. Both hind paws (right and left) were removed from each mouse at the ankles and weighed. The extent of edema was expressed as the difference in weight between the right and left paws from the same animal [13]. The anti-inflammatory activity was evaluated as the PIE.

\subsection{Cell lines and reagents}

The RAW 264.7 cells (Mice mononuclear macrophage leukemia cells) were purchased from the Science Experimental Center of Guangxi Medical University of (Nanning, Guangxi, China). 3-(4,5-Dimethylthiazol2-yl)-2,5-diphenyltetrazolium bromide (MTT), NF-k B p65 (D14E12) XPRabbit mAb, I k B-a (L35A5) Mouse mAb (Amino-terminal Antigen), Phospho-NF-k B p65 (Ser536) (93H1) Rabbit mAb, Phospho-l к B-a (Ser32) (14D4) Rabbit mAb, IKK-a (3G12) Mouse mAb, IL-6 (D5W4V) XPRabbit mAb (Mouse Specific), TNF-a (D2D4) XPRabbit mAb (Mouse Specific), IKKß (D30C6) Rabbit mAb, $\beta$-Actin (13E5) Rabbit mAb, Cox2 (D5H5) XP Rabbit mAb, Toll-like Receptor 4 (D8L5W) Rabbit mAb (Mouse Specific), Phospho-IKKa/ $\beta$ (Ser176/180) (16A6) Rabbit mAb, anti-mouse IgG, and anti-rabbit IgG were purchased from CST (Cell Signaling Technology, Beverly, MA, USA). Anti-IL-1 beta, and Anti-iNOS were purchased from Abcam (UK).

\subsection{Cell culture}

The RAW264.7 cells were maintained at $37^{\circ} \mathrm{C}$ in DMEM (GIBCO, Grand Island, NY, USA) containing $10 \%$ fetal bovine serum (FBS from GIBCO, Grand Island, NY, USA), penicillin $(100 \mathrm{U} / \mathrm{mL})$, and streptomycin $(100 \mu \mathrm{g} / \mathrm{mL})$ in a moisturized atmosphere with $5 \% \mathrm{CO}_{2}$.

\subsection{Cell viability assay}

The cell density of mouse RAW264.7 cells in logarithmic growth phase was adjusted to $1.0 \times 10^{5} / \mathrm{mL}$, inoculated in 96 -well culture plate at $100 \mu \mathrm{L}$ per well, cultured at $37^{\circ} \mathrm{C}$ for 24 hours, and then abandoned the original culture medium, with the medium containing $10 \%$ fetal bovine serum as the blank control group, the medium containing $0.5 \% \mathrm{DMSO}$ as the solvent control group, and different concentrations of drugs as the administration group. The culture medium containing $10 \%$ fetal bovine serum and the medium containing $0.5 \%$ DMSO were used as blank control group and the solvent control group, 
respectively. There were 3 wells in each group, and $100 \mu \mathrm{L}$ was administered into each hole. The cells in each group were cultured at $37{ }^{\circ} \mathrm{C}$ using $5 \% \mathrm{CO}_{2}$ for 24 hours, the original medium was then abandoned, and $10 \%$ MTS $100 \mu \mathrm{L}$ was added to each well. After putting back into the incubator for 2 hours incubation, the A490 value of each hole was determined by an enzyme labeling instrument. Using the cell survival rate of the blank control group as $100 \%$, the cell survival rate of each treatment group was calculated according to the following formula $(\%)=(O D$ value of the administration group $/$ OD value of the blank group) $\times 100 \%$.

\subsection{Establishment of a model of RAW264.7 cells resisting LPS stimulation}

Mouse RAW264.7 cells in the logarithmic growth phase were selected and the cell density was adjusted to $1.0 \times 10^{5} / \mathrm{mL}$, followed by incubation in a 96 -well culture plate at $100 \mu \mathrm{L}$ per well. The original medium was discarded after being cultured at $37{ }^{\circ} \mathrm{C}$ used $5 \% \mathrm{CO}_{2}$ for 24 hours. Different concentrations ( 0.1 $\mu \mathrm{g} / \mathrm{mL}, 0.5 \mu \mathrm{g} / \mathrm{mL}, 1 \mu \mathrm{g} / \mathrm{mL}, 5 \mu \mathrm{g} / \mathrm{mL}$, and $10 \mu \mathrm{g} / \mathrm{mL}$ ) of LPS groups were adjusted, each group had 3 multiple holes, and the final volume of each hole was $100 \mu \mathrm{L}$. After mouse RAW264.7 cells were induced by LPS for 24 hours, the supernatant was collected and the concentration of LPS-induced NO was measured according to the operating instructions of the NO kit to determine the best induction dose of LPS.

\subsection{NO activity assay}

The inflammation model of LPS-induced RAW264.7 cells was established according to the method of establishing inflammation model in vitro under item 2.10, employing the medium as the blank control group, $0.5 \%$ DMSO containing solvent as a model group, and different concentrations of drugs as the treatment group, with 3 multiple holes in each group, and the final volume of each enzyme-labeled hole as $100 \mu \mathrm{L}$. At the end of the culture, the supernatant of $50 \mu \mathrm{L}$ cells was absorbed, and the concentration of NO was determined according to the operating instructions of the NO kit.

\subsection{ELISA assay to test TNF-a, IL-6}

The inflammatory model in vitro was established according to 2.10 , and the corresponding drugs were given. After completing the culture, the contents of TNF- $a$ and IL- 6 in the supernatant of the cells were determined. The cytokine levels were measured with the corresponding ELISA kits following the manufacturer's instructions. The absorbance of each sample was determined by an enzyme plate spectrophotometer at $450 \mathrm{~nm}$ wavelength. The standard curve was set with the American Origin 8 drawing standard: the format was set for highlighting: the quasi-curve was highlighted and the concentrations of IL-6 and TNF- $a$ cytokines were calculated. 


\subsection{Protein extraction and western blotting analysis}

Cells were initially treated with flavonoid-enriched extracts or 8 compounds and with LPS $(1 \mu \mathrm{g} / \mathrm{mL})$ for 24 hours. Nuclear and cytosolic lysate extracts were collected using a commercial kit following the manufacturer's instructions (Beyotime Institute of Biotechnology). All procedures were performed at $4^{\circ} \mathrm{C}$ or in ice. Protease and phosphatase inhibitors were mixed with each lysate and reagents just before use. Briefly, cell pellets were added to $200 \mu \mathrm{L}$ cytoplasmic extraction reagent $\mathrm{A}$, then completely suspended and dispersed using vigorous vortex for $5 \mathrm{~s}$, followed by stirring in an ice bath for 10-15 min. The contents were then mixed with $10 \mu \mathrm{L}$ cytoplasmic extraction reagent $B$ and vortexed violently, centrifuged at $16,000 \mathrm{~g}$, at $4^{\circ} \mathrm{C}$ for $5 \mathrm{~min}$. Supernatants were collected from the lysates as cytoplasmic proteins. The remnants of cell pellets were mixed with $50 \mu \mathrm{L}$ nuclear extraction reagent and homogenized on ice, then vortexed violently for 15-30 s after every 1-2 minutes for 30 minutes. The admixtures were centrifuged at $16,000 \mathrm{~g}$ for $10 \mathrm{~min}$ at $4^{\circ} \mathrm{C}$, and supernatants were collected as the nuclear extract. The protein concentration was analyzed with the protein quantification method of BCA.

Total proteins were electrophoresed on SDS-PAGE and transferred onto a PVDF membranes (Bio-Rad Laboratories, Hercules, CA, USA). The membranes were washed with TBST buffer, treated with $5 \%$ skimmed milk for $2 \mathrm{~h}$ at $25^{\circ} \mathrm{C}$, and then treated with primary antibodies for $12 \mathrm{~h}$ at $4^{\circ} \mathrm{C}$. After being washed with TBST, the membranes were probed with secondary antibody at room temperature. Finally, the protein blots were read on a ChemiDOC XRS + system (Bio-Rad Laboratories).

\subsection{Statistical analysis}

Quantitative data were presented as the mean \pm standard deviation. Multiple comparisons between experimental groups were distinguished by single-factor analysis of variance. The difference was statistically significant $(p<0.05)$. Statistical analysis was performed using GraphPad Prism version 7 (America) and Origin version 8 (America)

\section{Results}

\subsection{Separation and Identification of compounds from different fractions}

Compounds 1-11 were obtained from C1 by extraction, silica gel column, D101 macroporous resin, and semi-preparative high-performance liquid chromatography (Fig.1). Their structures were determined via NMR and mass spectrometry (MS) techniques. Furthermore, compound 1 was chosen as an example to indicate the structural identification of other compounds in the next section. 
Compound 1 was obtained as an amorphous brown powder. $\mathrm{Mg}-\mathrm{HCl}$ and Molisch reactions were positive, which indicated that compound 1 flavonoid. The molecular formula was determined as $\mathrm{C}_{27} \mathrm{H}_{30} \mathrm{O}_{15}$ by HRESI-MS at $\mathrm{m} / \mathrm{z}$ 595.16. Its structure was determined by $1 \mathrm{D}(1 \mathrm{H}, 13 \mathrm{C})$ and $2 \mathrm{D}$ (HSQC and HMBC) NMR experiments. The ${ }^{1} \mathrm{H}-\mathrm{NMR}$ spectrum of compound 1 was obtained with a carefully dried sample of 1 dissolved in DMSO-d6. which showed the shift at 13.50 (s), indicating a skeleton of a flavonol with a free hydroxyl group at $\mathrm{C}-5$ position. Ring $\mathrm{A}$ and ring $\mathrm{C}$ had three protons for $\mathrm{H}-3, \mathrm{H}-6$ and $\mathrm{H}-8$ confirmed by their downfield shift at $6.98(\mathrm{~s}, 1 \mathrm{H}), 6.88(\mathrm{~s}, 1 \mathrm{H} 囚$ and $6.56(\mathrm{~s}, 1 \mathrm{H})$. The data suggested that $\mathrm{C}-7$ and $\mathrm{C}-5$ were both substituted. The aromatic protons of $B$ ring appeared as a doublet $(8.09,2 \mathrm{H}, \mathrm{J}=8.5 \mathrm{~Hz})$ assigned to $\mathrm{H}-2^{\prime}, 6^{\prime}$ and a doublet $(\delta 7.21,2 \mathrm{H}, \mathrm{J}=8.5 \mathrm{~Hz})$ for $\mathrm{H}^{\prime} 3^{\prime}, 5^{\prime}$ with a downfield shift consisting of $A A^{\prime} \mathrm{BB}^{\prime}$ coupling system, which indicated that $\mathrm{C}-\mathrm{4}^{\prime}$ ' was substituted. Moreover, the spectrum exhibited two anomeric proton signals resonated at $5.04(1 \mathrm{H}, \mathrm{d}, \mathrm{J}=7.2 \mathrm{~Hz}), 4.61(1 \mathrm{H}, \mathrm{d}, \mathrm{J}=9.4 \mathrm{~Hz})$, corresponding to two-configuration glucose units and the shift at $\delta: 5.04 \sim 3.20$ assigned to sugar protons overlapped with -OH proton signals. The coupling constant of anomeric proton showed the $\beta$-configurations of the glucose.

The ${ }^{13} \mathrm{C}-\mathrm{NMR}$ spectrum confirmed the presence of 13 carbon signals assigned to the flavonol and 12 carbon signals for the sugar units. The compound can be determined as flavonoids by five SP2 hybrid ether oxygen carbon signals at $\delta 182.8(\mathrm{C}=0), 164.7,160.9,164.3$ and 157.2 confirming the above deduction. Moreover, the group of signals at $\delta 102.8,74.0,79.2,70.5,77.0,61.5$ and $\delta 100.4,76.6,81.3$, $73.5,71.3,65.5$ corresponded to $\beta$-D-glucose. In the HSQC spectrum, proton signals at $\delta 6.98,6.88$ and 6.56 were correlated with $\delta 103.8,90.8$ and 94.2 respectively, which proved that $\delta 6.98,6.88$ and 6.56 were assigned to $\mathrm{H}-3, \mathrm{H}-8$ and $\mathrm{H}-6$.

In the HMBC, $\delta 6.56$ showed a long-range correlation with 160.9 and 164.3. Moreover, $\delta 6.88$ showed a long-range correlation with 164.3 and 157.2. C-5 at 160.9, indicated that C-7 at $164.3, \mathrm{C}-9$ at 157.2 and C7 were oxygenated. Furthermore, $\delta 8.09\left(\mathrm{H}-2^{\prime}, 6^{\prime}\right)$ showed a long-range correlation with 160.8, and 164.7. Similarly, $\delta 7.21\left(\mathrm{H}-3^{\prime}, 5^{\prime}\right)$ showed a long-range correlation with 124.3 and 160.8 , which confirmed C-2 at 164.7, C-1'at 124.4, C-4' at 160. 8 and that C-4' was oxygenated.

The position of the glucose unit was assigned to $\mathrm{C}-4$ ' on the basis of HMBC correlation between the anomeric proton of glucose at 5.04 and $\mathrm{C}-4^{\prime}$ at 160.8 . The anomeric proton signals of sugar $4.62\left(\mathrm{H}-\mathbf{1}^{\prime \prime}\right)$ remote related with $65.5(\mathrm{C}-6 ")$ on the basis of $\mathrm{HMBC}$, which proved that the two $\beta$-glucopyranoside moieties were linked to C-4" and C- 6 "', respectively. The results were found to be in agreement with the proposed structure as 5,7-dihydroxy-flavone-4'-(6"-O- $\beta$-D-glucopyranoside)-O- $\beta$-D-glucopyranoside.

\subsection{Anti-inflammatory evaluation of Xylene-induced ear edema and Carrageenan-induced paw edema}

After statistical processing, the inhibition rate of the blank control group and the test group on the degree of auricle swelling and paw edema of mice were obtained. The inhibition rate $\% \bigotimes$ of the five fractions $(\mathrm{C} 1, \mathrm{C} 11, \mathrm{C} 12, \mathrm{C} 13$ and $\mathrm{C} 120)$ in the xylene-induced mice ear edema and carrageenan-induced mice paw 
edema compared to the standard drugs dexamethasone are shown in Fig.3, respectively. Compared to the blank group, extracts $\mathrm{C} 11$ increased the degree of auricle swelling and paw edema in mice. The inhibition rate $\%$ \% of $\mathrm{C} 13$ is not significant in the xylene-induced mice ear edema. Treatment with C1, C12 and C120 significantly suppressed ear edema and paw edema.

Therefore, based on the above experimental results of ear swelling and paw edema, fractions खC1,C12,C120邓were selected for further mechanistic investigation.

\subsection{Cell viability in RAW264.7}

The results of MTS detection showed that, the concentration of C1, C12, and C120 (15.625 $1000 \mu$ $\mathrm{g} / \mathrm{mL}$ ) did not affect the cell viability of RAW264.7 macrophages as compared to the negative control (Fig.4), indicating minor cytotoxic or stimulatory effect of $\mathrm{C} 1, \mathrm{C} 12$, and $\mathrm{C} 120$ up to a concentration of $1000 \mu \mathrm{g} / \mathrm{mL}$ on RAW264.7 cells. Therefore, the largest concentration of $500 \mu \mathrm{g} / \mathrm{mL}$ was used for cell culture.

\subsection{NO release quantity}

NO is an important inflammatory mediator, which is related to many inflammatory diseases. LPS can significantly promote the release of NO from macrophage RAW264.7. Therefore, the inhibitory effect on the release of NO can be used to evaluate the anti-inflammatory effect of the extract of Thlaspi arvense Linn and compounds isolated from it. Compared to the model group, the extracts of Thlaspi arvense Linn (C1, C12, and C120) could effectively inhibit the production of $\mathrm{NO}$ at the concentration of $62.5-1000$ $\mu \mathrm{g} / \mathrm{mL}$. The inhibition rate was $50 \%$ when the concentration reached $500 \mu \mathrm{g} / \mathrm{mL}$. The MTS results further showed that the cell viability decreased by $10 \%$ at a concentration of $1000 \mu \mathrm{g} / \mathrm{mL}$. Therefore, concentrations of 125,250 , and $500 \mu \mathrm{g} / \mathrm{mL}$ were selected for further study.

\subsection{Modulation of cellular production of IL-6 and TNF-a by extracts from the Thlaspi arvense Linn}

In this experiment, lipopolysaccharide stimulates RAW264.7 macrophages to overexpress proinflammatory cytokines COX-2 and IL-6. To confirm the anti-inflammatory effect of the extracts of Thlaspi arvense Linn, the release of IL- 6 and TNF- $a$ was detected by an ELISA kit. The results showed that after the intervention of C1, C12 and C120, the levels of TNF- $a$ and IL- 6 in LPS-stimulated RAW264.7 cells decreased significantly in a dose-dependent manner (Fig.6). To sum up, the extract of Thlaspi arvense Linn may play a good anti-inflammatory role by inhibiting the excessive production of TNF-a and IL-6 in the process of inflammation. The results showed that $\mathrm{C} 12$ had the best anti-inflammatory effect and the most significant inhibitory effect against IL- 6 and TNF-a produced by LPS-stimulated macrophage 264.7. Therefore, $\mathrm{C} 12$ was selected to make an in-depth study on the mechanism. 


\subsection{Effects of $\mathrm{C} 12$ on protein expression of iNOS, COX-2, proteins of NF-K B pathways in LPS-induced RAW 264.7 cells}

The expression of iNOS and COX-2 was significantly up-regulated by LPS. The expression of these two proteins was significantly improved in a dose-dependent manner after different concentrations of $\mathrm{C} 12$ were administered (Fig. 7). The expressions of iNOS and COX-2 were not significantly affected by 125 and $250 \mu \mathrm{g} / \mathrm{mL}$ of $\mathrm{C} 12$. The NOS expression was significantly inhibited by $500 \mu \mathrm{g} / \mathrm{mL}$ of $\mathrm{C} 12$, whereas the LPS-induced COX-2 expression was also significantly decreased by $125-500 \mu \mathrm{g} / \mathrm{mL}$ of $\mathrm{C} 12$. To elucidate the anti-inflammatory mechanism of the extract C12 more clearly, the NF-K B pathway was studied.

In unstimulated RAW264.7 cells, NF-к B was inhibited by I к B kinase and remained in the cytoplasm. When RAW264.7 cells were stimulated by LPS, the inflammatory signals lead to I $\mathrm{k} B$ phosphorylation and degradation. NF-K B is phosphorylated and transferred from the cytoplasm to the nucleus, which promotes the secretion of related inflammatory factors through a series of transcription and translation. C12 can inhibit the overexpression of TLR-4 protein in LPS-induced RAW264.7 macrophages, in addition to the inhibition of the hyperphosphorylation of key proteins downstream of TLR-4 in RAW264.7 macrophages.

To explore the mechanism of the anti-inflammatory effect of $\mathrm{C} 12$, we detected the expression of related proteins in the classical TLR-4/NF-K B signal pathway that mediates the inflammatory response of RAW264.7 macrophages.

As shown in Fig. 7A, stimulation of LPS $(1.0 \mu \mathrm{g} / \mathrm{mL})$ with $\mathrm{C} 12$ for 24 hours could significantly induce the overexpression of TLR-4, and different doses of C12 could inhibit the overexpression of TLR-4 to different extents. LPS can significantly induce the phosphorylation of NF-K B p65, leading to the enhanced production of inflammatory response. At the same time, different doses of $\mathrm{C} 12$ could inhibit the phosphorylation level of NF-k B p65 to different extents, especially at $500 \mu \mathrm{g} / \mathrm{mL}$ (Fig.7B). Besides, the level of I k B-a increased significantly with the increase of C12 concentration (Fig. 7C), indicating that C12 could inhibit the degradation of I k B-a. Subsequently, the dissociation of NF-k B decreased, which prevented the production of pro-inflammatory factors. Inhibition of the phosphorylation level of I k B-a to different extents can also suppress the depolymerization of I $\mathrm{k}$ B-a polymer and can exert an antiinflammatory effect. At the same time, the release of inflammatory factor IL-1 $\beta$ secretory protein was also significantly inhibited. Overall, the results confirmed that $\mathrm{C} 12$ had an obvious inhibitory effect at 500 $\mu \mathrm{g} / \mathrm{mL}$. The overall inflammatory signaling pathway is shown in Fig. 7.

\section{Discussion}

In this study, it was confirmed that the extracts from the Thlaspi arvense Linn and its isolated flavonoids could inhibit xylene-induced ear edema and carrageenan-induced foot swelling in mice. Furthermore, it 
was noted that the extracts and isolated compounds also exhibited inhibitory effect against the acute inflammation in vivo. Besides, the extracts $\mathrm{C} 1, \mathrm{C} 12$, and $\mathrm{C} 120$ of Thlaspi arvense Linn inhibited the expression of TNF- $a$, COX-2, and the release of NO in LPS-induced RAW264.7 macrophages in a dosedependent manner, as well as the excessive release of proinflammatory cytokines IL-1 $\beta$ and IL-6. Therefore, these results further proved the anti-inflammatory activity of the extracts of Thlaspi arvense Linn. As a kind of plant that can be eaten and used medicinally, Thlaspi arvense Linn has a very broad application prospect. Related studies have shown that the flavonoids used in daily diet has good antiinflammatory effects both in vitro and in vivo [14]

NO release is considered to be an inflammatory marker [15]. TNF- $\alpha$ is considered to be a pro-inflammatory factor, and its role depends on the target immune cells and the process of apoptosis [16]. IL-6 is a multipotent cytokine that plays a central role in the inflammatory process and is also an activator of signal transducer and transcription. It causes the blocking of apoptosis in the inflammatory process and allows cells to survive in a toxic environment [17]. COX-2 protein is an inducible pro-inflammatory molecule [18]. The results showed that $\mathrm{C} 12$ could significantly reduce the concentration of inflammatory cytokines (IL-6 and TNF- a), inhibit the release of NO from LPS-stimulated RAW264.7 cells in a dosedependent manner. Moreover, C12 can also significantly inhibit the expression of iNOS and COX-2 at a dose of $500 \mu \mathrm{g} / \mathrm{mL}$. The experimental results obtained in this work have proved the significant antiinflammatory effect of the extracts of Thlaspi arvense Linn.

Endogenous molecules are released by injured tissues and necrotic cells activate the pro-inflammatory response by interacting with TLR-4[19]. After LPS stimulation, TLR-4 induces inflammatory response through NF-K $B[6,7]$. NF-K $B[20-22]$ plays a key role in the response to various pro-inflammatory stimuli. The rapid phosphorylation of $\mathrm{I} \mathrm{K} B$ activates the nuclear factor into an active form. After activation, the free p65 protein is transferred from the cytoplasm to the nucleus, where it binds to its downstream genes, and induces the transcription of pro-inflammatory mediators[23]. It seems that a central pathway mediates the anti-inflammatory effects of several flavonoids through the inhibition of signals by NF-K $\mathrm{B}[24]$.

C12 can strongly inhibit LPS-induced overexpression of TLR-4, COX2, iNOS, and TNF-a proteins, as well as the excessive release of IL- 6 and IL-1 $\beta$ in macrophages. Furthermore, $\mathrm{C} 12$ also suppresses the phosphorylation of downstream effector I k B-a and NF-k B p65. At the same time, after the dissociation of I $\mathrm{K} B$, the nuclear translocation of $\mathrm{p} 65$ is a very critical step in the NF-k B pathway [25]. The excessive LPS-induced translocation of NF-K B p65 to the nucleus was inhibited, which further confirmed the inhibitory effect of $\mathrm{C} 12$ on the activation of NF-k B. These results suggested that $\mathrm{C} 12$ inhibits the LPSinduced macrophage inflammation through NF-k B mediated pathway.

The identification of active components is a very important issue in the research of traditional Chinese medicine, which plays a targeted role for determining the efficacy of these medicines. In this study, it was found that there were a large number of flavonoids in Thlaspi arvense Linn, which need to be isolated, identified, and detected. This study confirmed that there were 11 kinds of main flavonoids in the extract 
of Thlaspi arvense Linn. However, additional research is needed to understand further the interaction of these flavonoids.

\section{Conclusion}

To sum up, the results of this study show that the flavonoid-rich Thlaspi arvense Linn has an antiinflammatory effect against the LPS-stimulated macrophages through the NF-K B-mediated signaling pathway. This study lays a foundation for further application of Thlaspi arvense Linn in the food and pharmaceutical industries and also provides a powerful tool for quickly discovering more potential components in other natural resources.

\section{Abbreviations}

COX-2, cyclooxygenase-2; I к B, inhibitory к B; IL-6, interleukin-6; IL-1 $\beta$, interleukin-1 $\beta$; iNOS, inducible nitric oxide synthase; LPS, lipopolysaccharide; NF-K $B$, nuclear factor-K $B$; NO, nitric oxide; TLR, toll-like receptor; TNF-a, tumor necrosis factor- $a ; C 1$, Water extraction and alcohol precipitation; $\mathrm{C} 12$, N-butanol fraction; C120, Total flavonoids;

\section{Declarations}

\section{Acknowledgements}

Not applicable.

\section{Authors' contributions}

XW, PKZ and XJL conceived and designed the study. XW and PKZ conducted the experiments. $\mathrm{HL}, \mathrm{XL}$, HUR and LYC provided the technical support and advices for the study. XW wrote the manuscript, LSW revised the manuscript. All authors contributed to the review and the approval of the final manuscript. All authors read and approved the final manuscript.

\section{Funding}

This work was supported by Guangxi Innovation-Driven Development Project (GuiKe AA18242040) and the high-level innovation team and outstanding scholar project of Guangxi institutions of higher education (guijiaoren (2014) 49 hao).

\section{Availability of data and materials}


The datasets used in this study are available from the corresponding author upon reasonable request.

\section{Ethics approval and consent to participate}

The animal experiments were performed as per Principles of Laboratory Animal Care and Use in Research (Ministry of Health, Beijing, China). The protocols for the animal experiments were approved by the Animals Ethics Committee of Guangxi Medical University.

\section{Consent for publication}

Not applicable.

\section{Competing interests}

The authors declare that they have no competing interests.

\section{Author details}

1 Medical College of Guangxi University, Nanning Guangxi 530004, PR China

2 Institute of Chemistry, Federal University of Mato Grosso do Sul, Campo Grande - MS, Brasil. 79074-460

\section{References}

1. Franceschi C, Campisi J. Chronic inflammation (inflammaging) and its potential contribution to ageassociated diseases. J Gerontol A Biol Sci Med Sci. 2014;69(Suppl 1):4-9.

2. Kotas ME, Medzhitov R. Homeostasis, inflammation, and disease susceptibility. Cell. 2015;160(5):816-27.

3. Ouellet M, Riendeau D, Percival MD: A high level of cyclooxygenase-2 inhibitor selectivity is associated with a reduced interference of platelet cyclooxygenase- 1 inactivation by aspirin. Proceedings of the National Academy of Sciences of the United States of America 2001, 98(25):14583-14588.

4. Moo-Huchin VM, Moo-Huchin MI, Estrada-Leon RJ, Cuevas-Glory L, Estrada-Mota IA, Ortiz-Vazquez E, Betancur-Ancona D, Sauri-Duch E. Antioxidant compounds, antioxidant activity and phenolic content in peel from three tropical fruits from Yucatan, Mexico. Food Chem. 2015;166:17-22.

5. Xu J, Zhou L, Sun L, Wang Z, Wang Y, Wang Y, He X: 3alpha-Angeloyloxy-ent-kaur-16-en-19-oic Acid Isolated from Wedelia trilobata L. Alleviates Xylene-Induced Mouse Ear Edema and Inhibits NF- 
kappaB and MAPK Pathway in LPS-Stimulated Macrophages. J Nat Prod 2020, 83(12):3726-3735.

6. Yu Y, Ge N, Xie M, Sun W, Burlingame S, Pass AK, Nuchtern JG, Zhang D, Fu S, Schneider MD, et al. Phosphorylation of Thr-178 and Thr-184 in the TAK1 T-loop is required for interleukin (IL)-1-mediated optimal NFkappaB and AP-1 activation as well as IL- 6 gene expression. J Biol Chem. 2008;283(36):24497-505.

7. Ajibade AA, Wang HY, Wang RF. Cell type-specific function of TAK1 in innate immune signaling. Trends Immunol. 2013;34(7):307-16.

8. Hojilla-Evangelista MP, Evangelista RL, Isbell TA, Selling GW. Effects of cold-pressing and seed cooking on functional properties of protein in pennycress (Thlaspi arvense L.) seed and press cakes. Ind Crops Prod. 2013;45:223-9.

9. Fan J, Shonnard DR, Kalnes TN, Johnsen PB, Rao S. A life cycle assessment of pennycress (Thlaspi arvense L.) -derived jet fuel and diesel. Biomass Bioenerg. 2013;55:87-100.

10. Fen T, Xie T. Analgesic and anti-inflammatory pharmacological effects of total flavonoids in mulberry bark. Lishizhen Medicine Materia Medica Research. 2013;24(11):2580-1.

11. Hosseinzadeh $H$, Younesi HM. Antinociceptive and anti-inflammatory effects of Crocus sativus $L$. stigma and petal extracts in mice. BMC Pharmacol. 2002;2:7.

12. Olajide OA, Awe SO, Makinde JM, Ekhelar Al, Olusola A, Morebise O, Okpako DT. Studies on the antiinflammatory, antipyretic and analgesic properties of Alstonia boonei stem bark. J Ethnopharmacol. 2000;71(1-2):179-86.

13. Jose' CT, Carvalho a. JAASb, MVJBa, a KCMPc, LIRGCa, SJSc, LPFa, c JKB: Anti-inflammatory activity of the crude extract from the fruits. of Pterodon emarginatus Vog. Journal of Ethnopharmacology 1999.

14. Chen L, Teng H, Jia Z, Battino M, Miron A, Yu Z, Cao H, Xiao J. Intracellular signaling pathways of inflammation modulated by dietary flavonoids: The most recent evidence. Crit Rev Food Sci Nutr. 2018;58(17):2908-24.

15. Guzik TJ, Korbut R, Adamek-Guzik T. Nitric oxide and superoxide in inflammation and immune regulation. J Physiol Pharmacol. 2003;54(4):469-87.

16. Sabry A, Sheashaa H, El-Husseini A, Mahmoud K, Eldahshan KF, George SK, Abdel-Khalek E, ElShafey EM, Abo-Zenah H. Proinflammatory cytokines (TNF-alpha and IL-6) in Egyptian patients with SLE: its correlation with disease activity. Cytokine. 2006;35(3-4):148-53.

17. Hodge DR, Hurt EM, Farrar WL. The role of IL- 6 and STAT3 in inflammation and cancer. Eur J Cancer. 2005;41(16):2502-12.

18. Hooshmand S, Kumar A, Zhang JY, Johnson SA, Chai SC, Arjmandi BH. Evidence for antiinflammatory and antioxidative properties of dried plum polyphenols in macrophage RAW 264.7 cells. Food Funct. 2015;6(5):1719-25.

19. Yu L, Wang L, Chen S. Endogenous toll-like receptor ligands and their biological significance. J Cell Mol Med. 2010;14(11):2592-603. 
20. Mora-Ramiro B, Jimenez-Estrada M, Zentella-Dehesa A, Ventura-Gallegos JL, Gomez-Quiroz LE, Rosiles-Alanis W, Alarcon-Aguilar FJ, Almanza-Perez JC. Cacalol Acetate, a Sesquiterpene from Psacalium decompositum, Exerts an Anti-inflammatory Effect through LPS/NF-KB Signaling in Raw 264.7 Macrophages. J Nat Prod. 2020;83(8):2447-55.

21. Lu MY, Chen CC, Lee LY, Lin TW, Kuo CF. N(6)-(2-Hydroxyethyl)adenosine in the Medicinal Mushroom Cordyceps cicadae Attenuates Lipopolysaccharide-Stimulated Pro-inflammatory Responses by Suppressing TLR4-Mediated NF-kappaB Signaling Pathways. J Nat Prod. 2015;78(10):2452-60.

22. Zhao JJ, Guo YQ, Yang DP, Xue X, Liu Q, Zhu LP, Yin S, Zhao ZM. Chlojaponilactone B from Chloranthus japonicus: Suppression of Inflammatory Responses via Inhibition of the NF-kappaB Signaling Pathway. J Nat Prod. 2016;79(9):2257-63.

23. Siebenlist U, Franzoso G, Brown K. Structure, regulation and function of NF-kappa B. Annu Rev Cell Biol. 1994;10:405-55.

24. Yuan X, Niu HT, Wang PL, Lu J, Zhao H, Liu SH, Zheng QS, Li CG. Cardioprotective Effect of Licochalcone D against Myocardial Ischemia/Reperfusion Injury in Langendorff-Perfused Rat Hearts. PLoS One. 2015;10(6):e0128375.

25. Oeckinghaus A, Ghosh S. The NF-kappaB family of transcription factors and its regulation. Cold Spring Harb Perspect Biol. 2009;1(4):a000034.

\section{Figures}




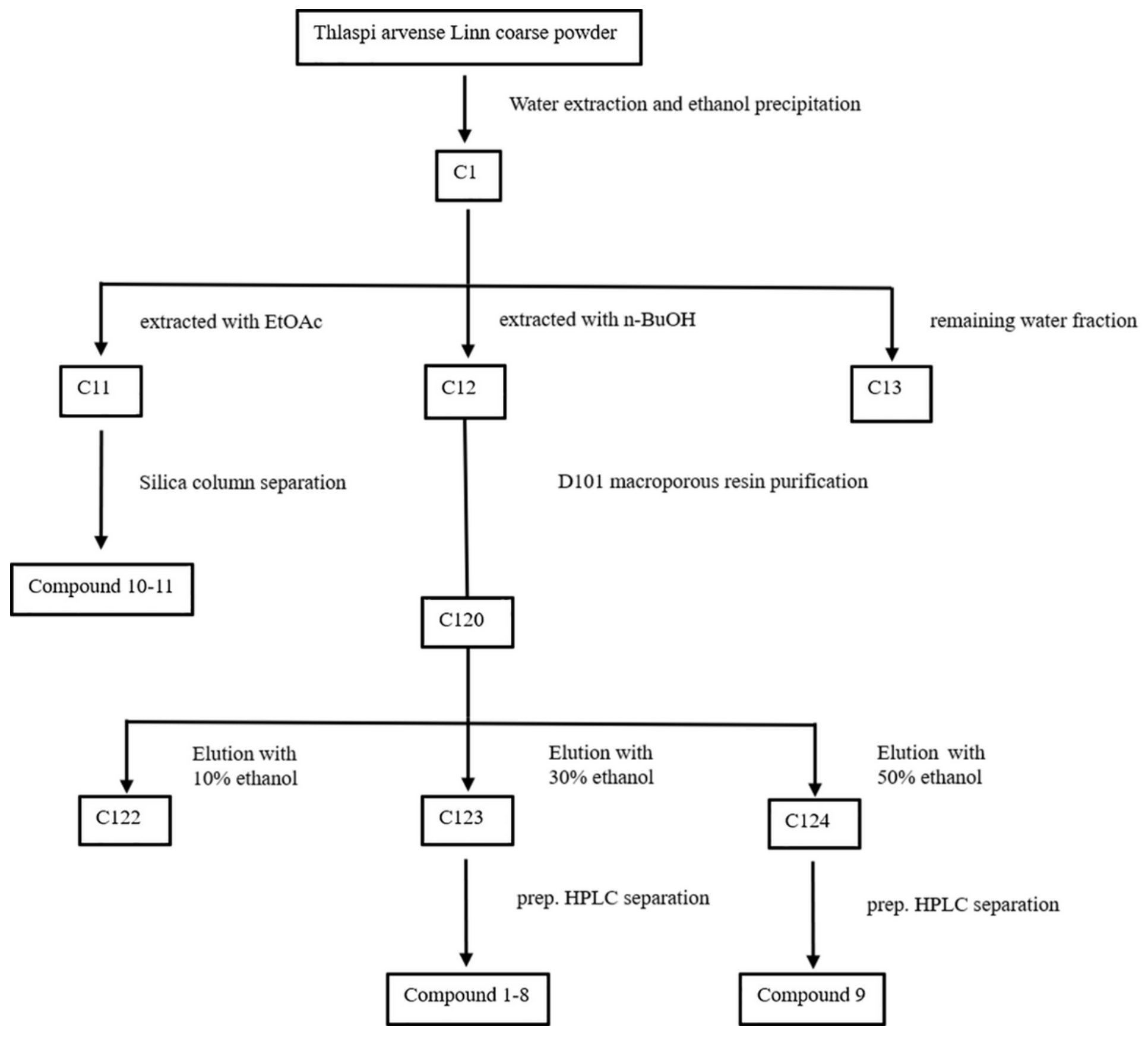

Figure 1

Flow chart of the separation and extraction of various components from Thlaspi arvense Linn. 


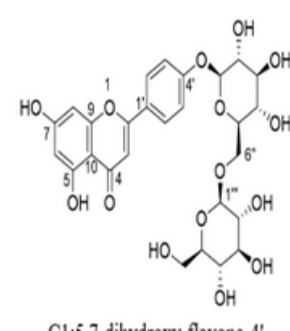

Cl:5,7-dihydroxy-flavone-4'( $6^{\prime \prime}$ - $\beta$-0-glucopyranoside). $\beta$ O-D-glucopyranoside

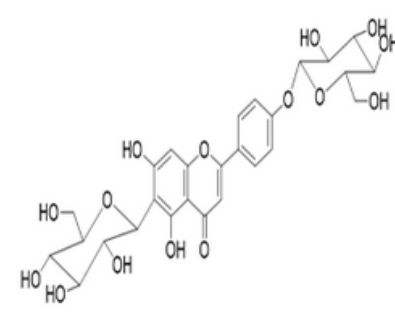

C2:isosapogenin

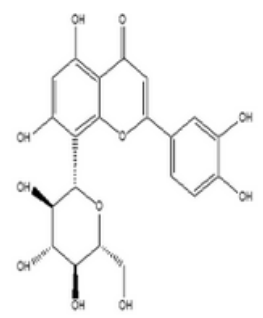

C3:Orientin

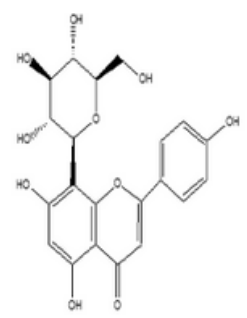

C4.vitexin

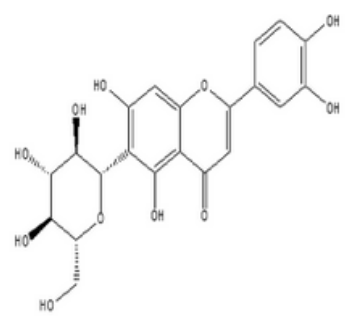

C5:Isoorientin

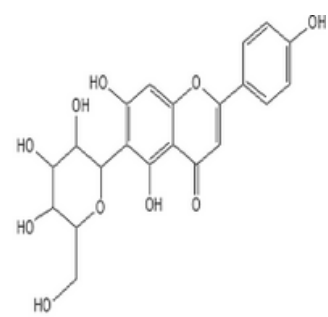

C6:Isovitexin

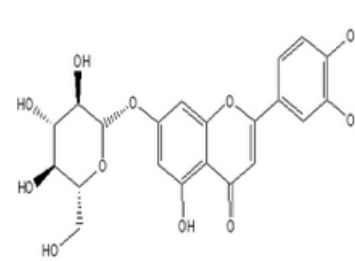

C7:luteolin 7-0- $\beta$.

D-glucoside

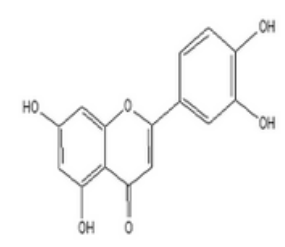

C8:Luteolin

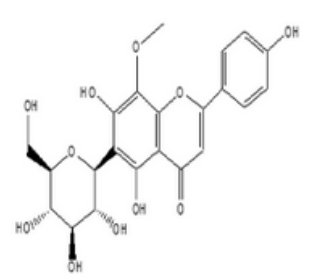

C9:8-methoxyvitexin

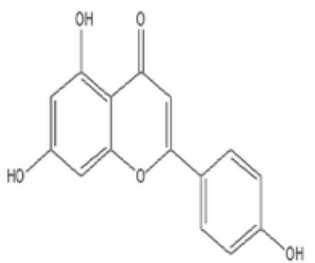

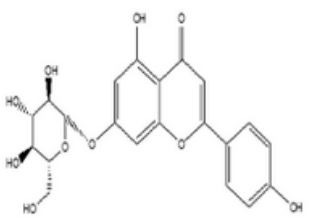

C11:Apigenin-7-0.

$\beta$-D-glucoside

Figure 2

Chemical structures of compounds 1-11 isolated from C1 of Thlaspi arvense Linn.

A

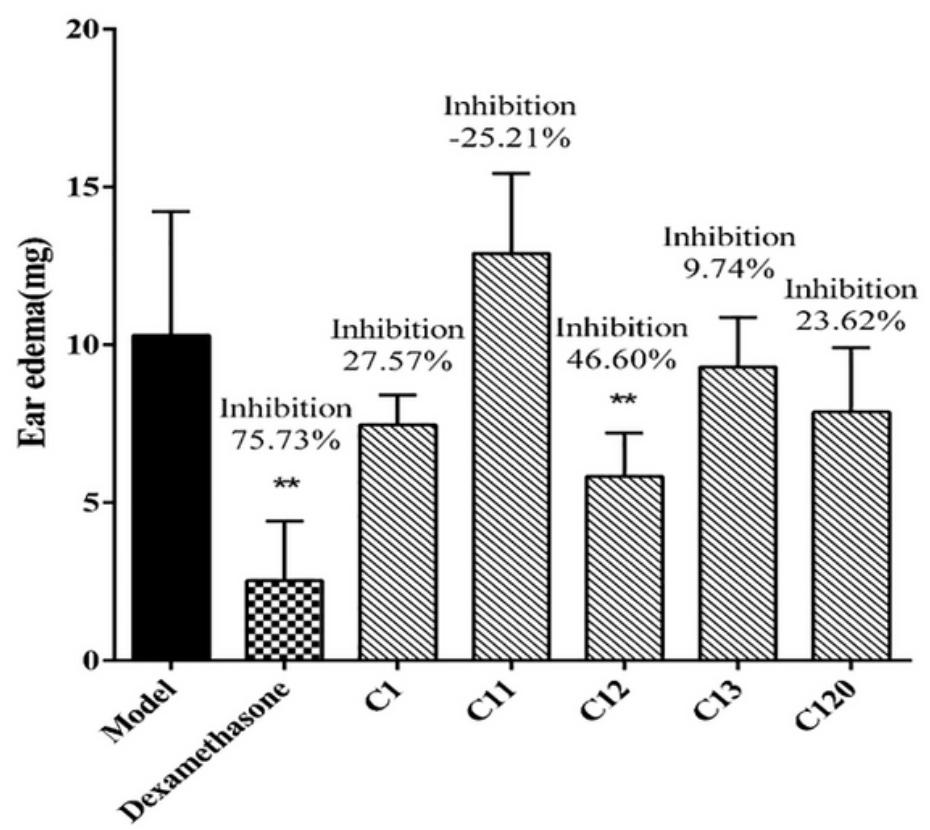

B

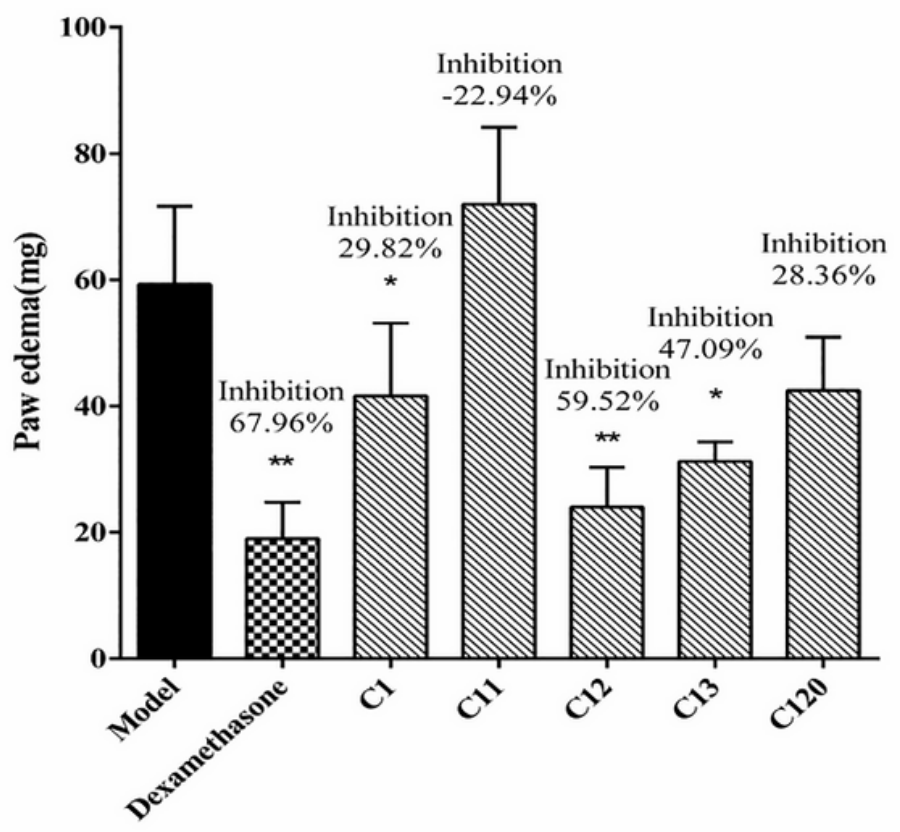

Figure 3

The inhibition rate (\% \%of fractions $(\mathrm{C} 1, \mathrm{C} 11, \mathrm{C} 12, \mathrm{C} 13$ and $\mathrm{C} 120)$ in xylene-induced mice ear oedema (compared to the standard drug dexamethasone) and arrageenan-induced mice paw oedema (compared to the standard drug dexamethasone).Vs Blank * $\mathrm{P}<0.05$, ** $\mathrm{P}<0.01$. 

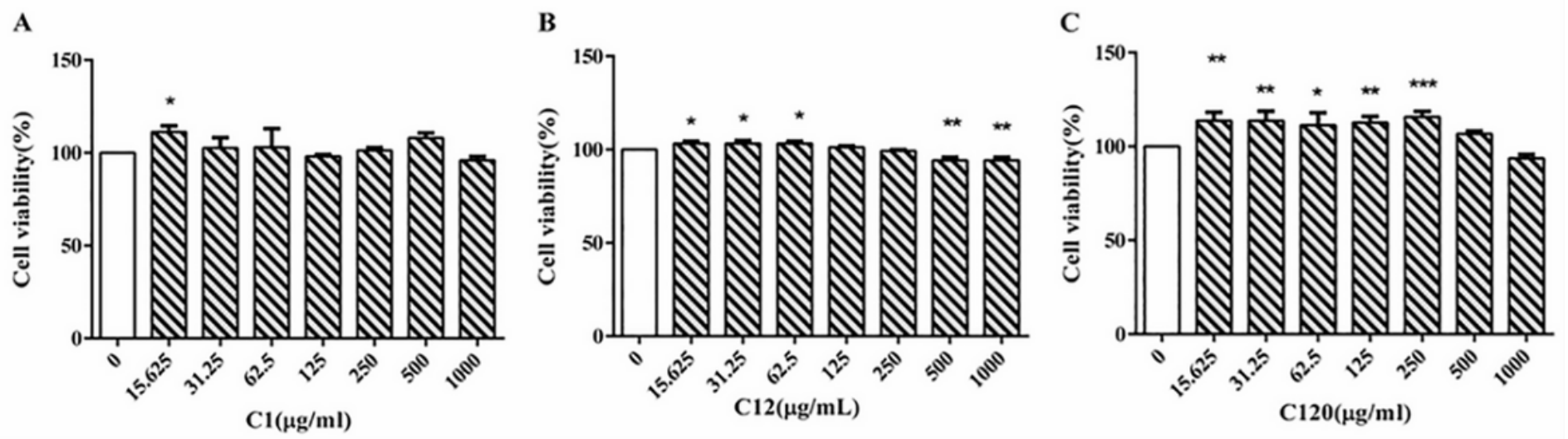

Figure 4

Effect of Thlaspi arvense Linn (A-C) on the viability of RAW 264.7 cells stimulated by LPS.A. Water extraction and alcohol precipitation; $\mathrm{B}$. N-butanol fraction; $\mathrm{C}$. Total flavonoids Average cell survival rate \pm SD $(n=3)$. Vs model * $P<0.05, * * P<0.01$, ${ }^{* *} P<0.001$
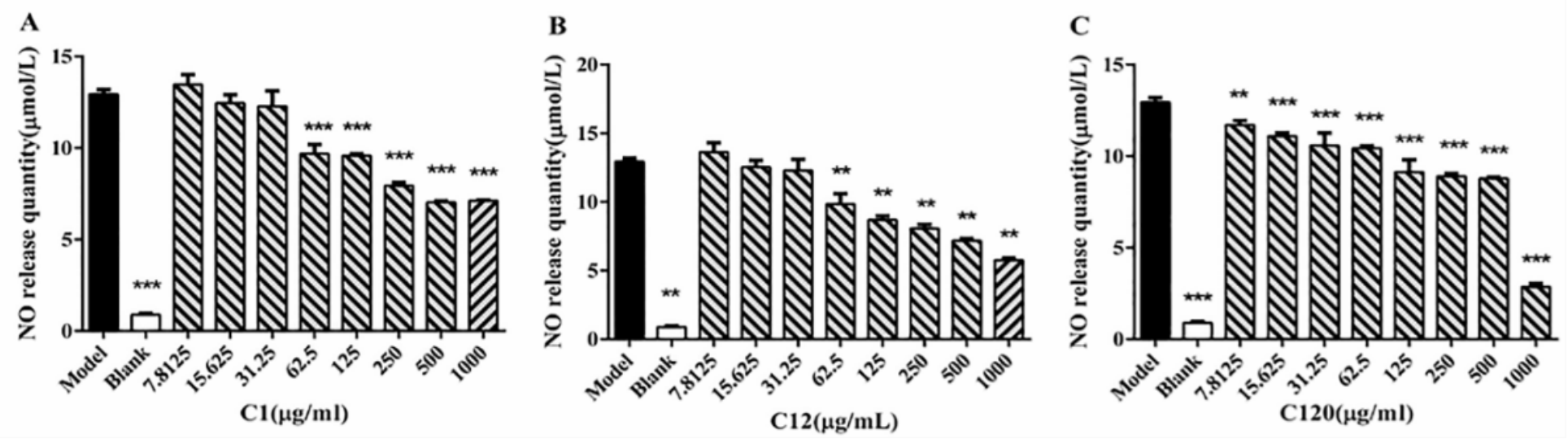

Figure 5

Effect of Thlaspi arvense Linn (A-C) on NO release from RAW 264.7 macrophages stimulated by LPS. A. Water extraction and alcohol precipitation B. N-butanol fraction C. Total flavonoids; Average NO release \pm SD $(n=3)$. Vs Blank, $\# P<0.05$, Vs model $* P<0.05, * \star P<0.01, * \star * P<0.001$ 
$\mathrm{C} 1$
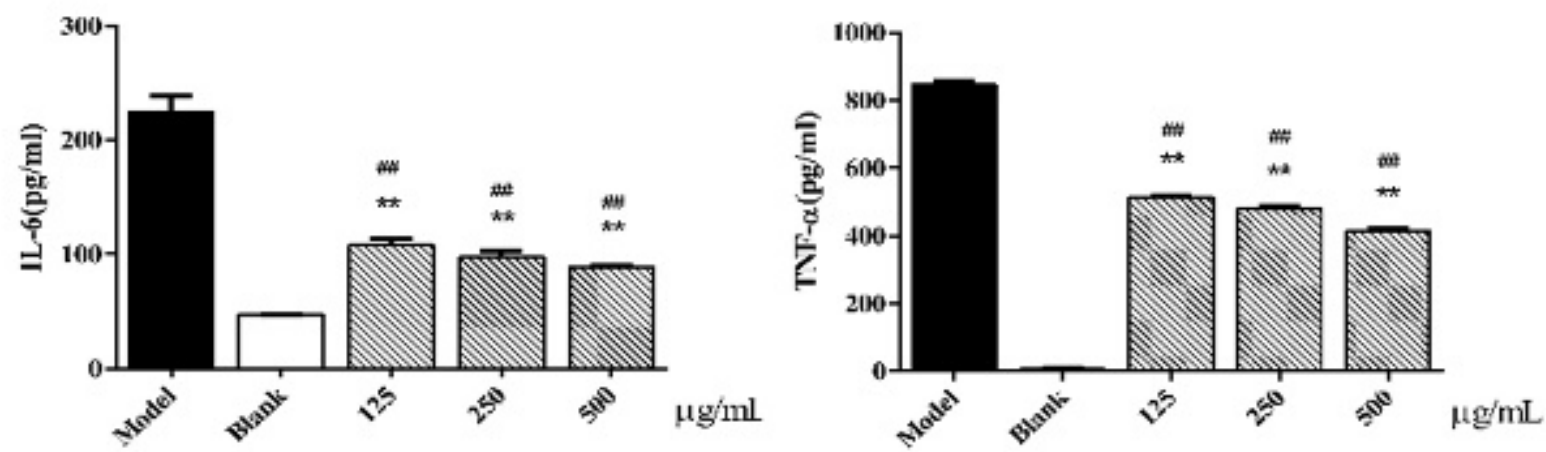

LPS $+-+++\operatorname{LPS}++_{+}+$

$\mathrm{C} 12$
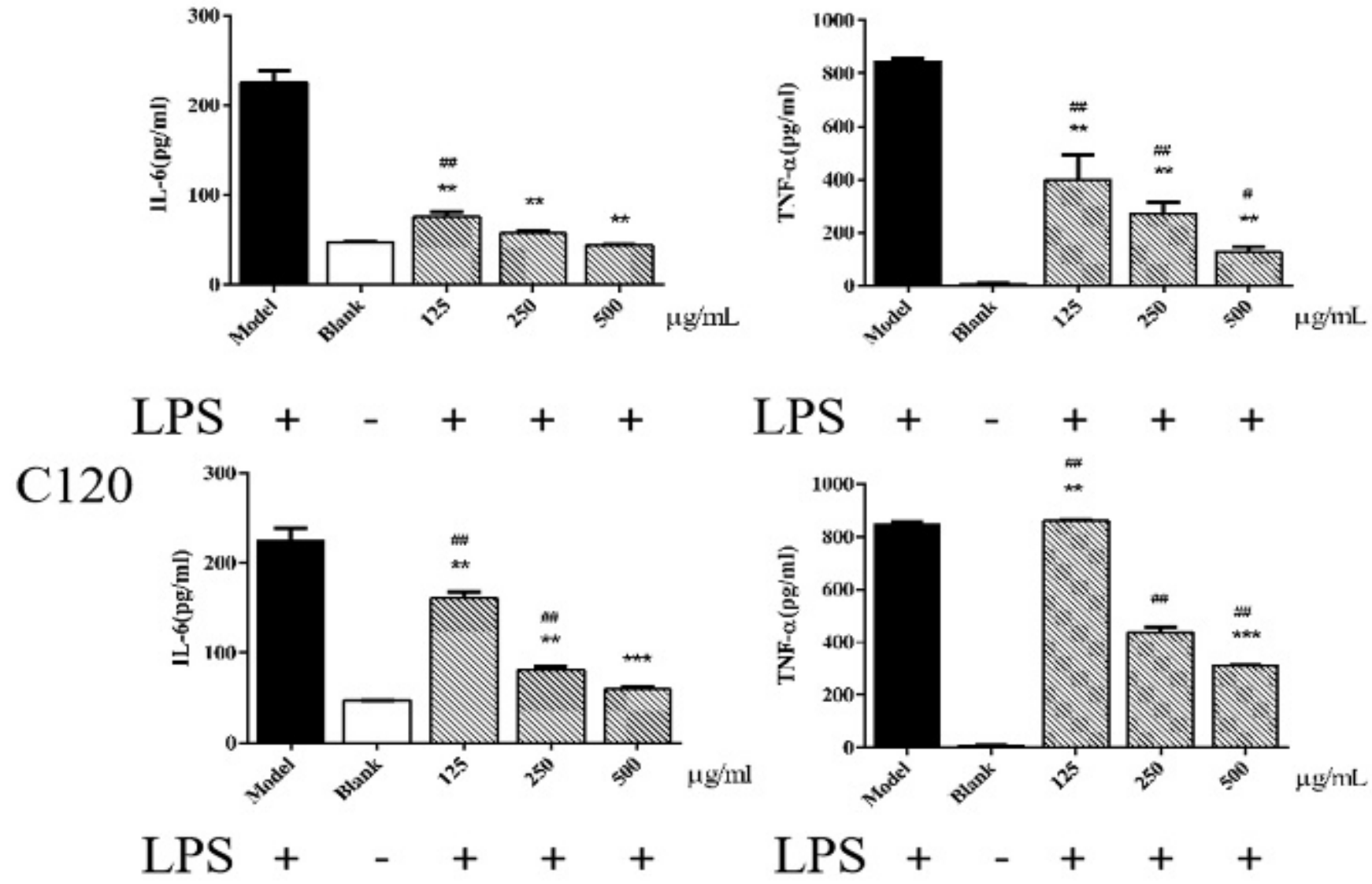

$\operatorname{LPS}+-+++$

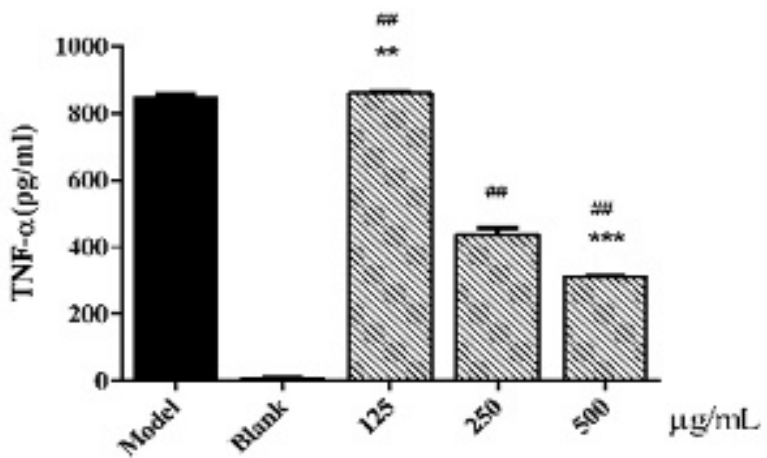

$\operatorname{LPS}+-+++$

$\mathrm{LPS}+-+++$

Figure 6

The effect of extract of Thlaspi arvense Linn (C1, C12, and C120) on the excessive release of proinflammatory cytokines IL- 6 and TNF-a by LPS-stimulated RAW264.7 macrophages. The concentrations of TNF- $a$ and IL- 6 in cell culture medium were detected by ELISA kit. The average value is $\pm S D(n=3)$. Vs Blank, $\# P<0.05$, Vs model $* P<0.05, * * P<0.01$, $* \star * P<0.001$. 
A
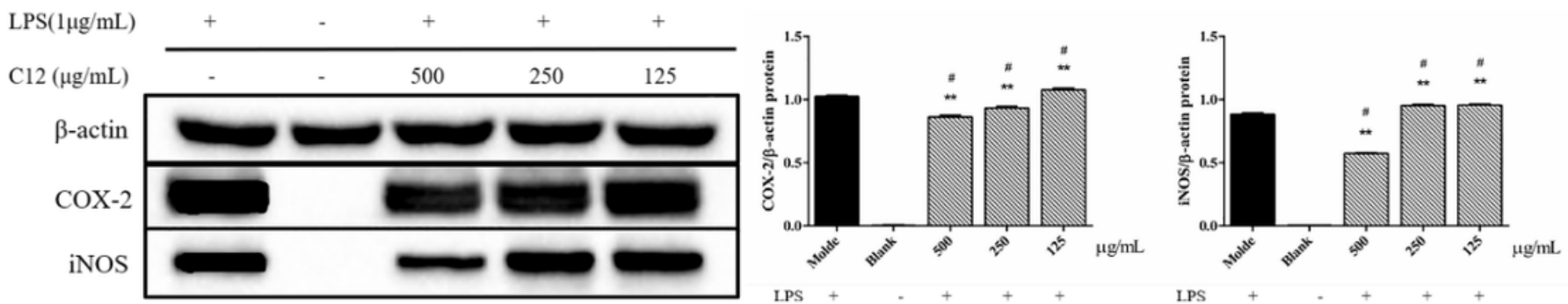

B
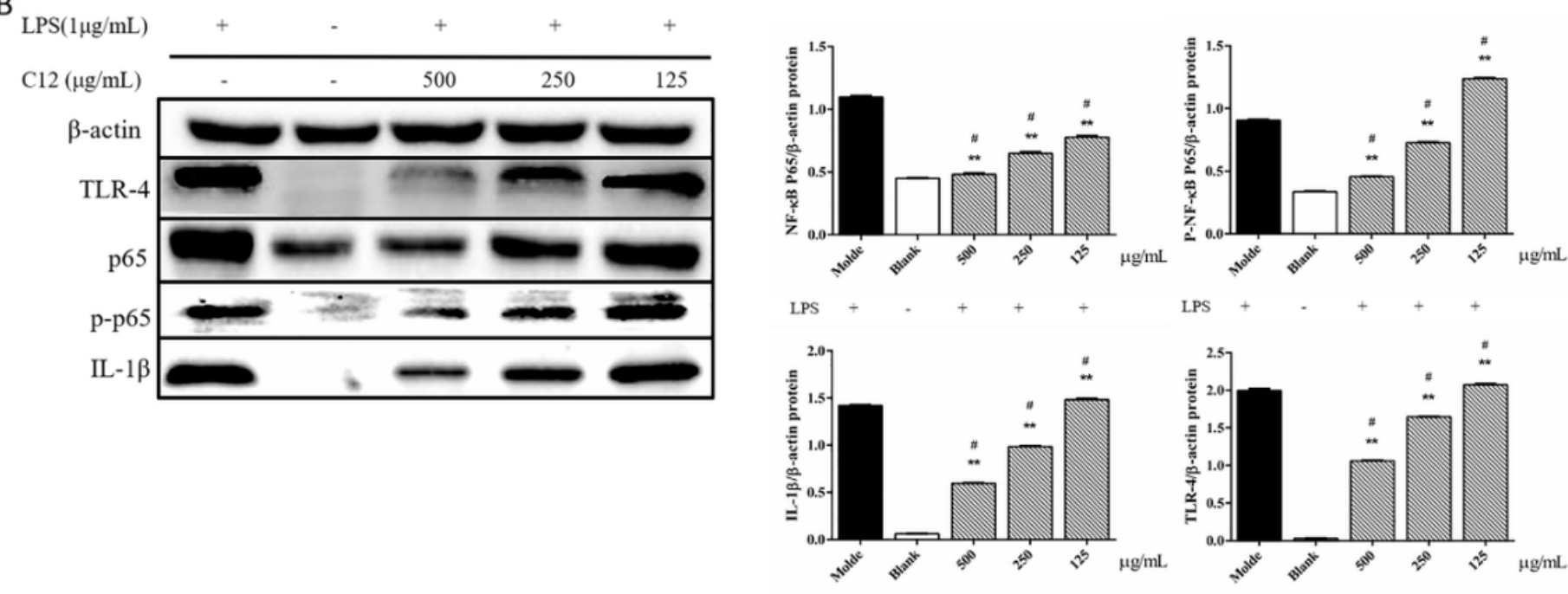

C
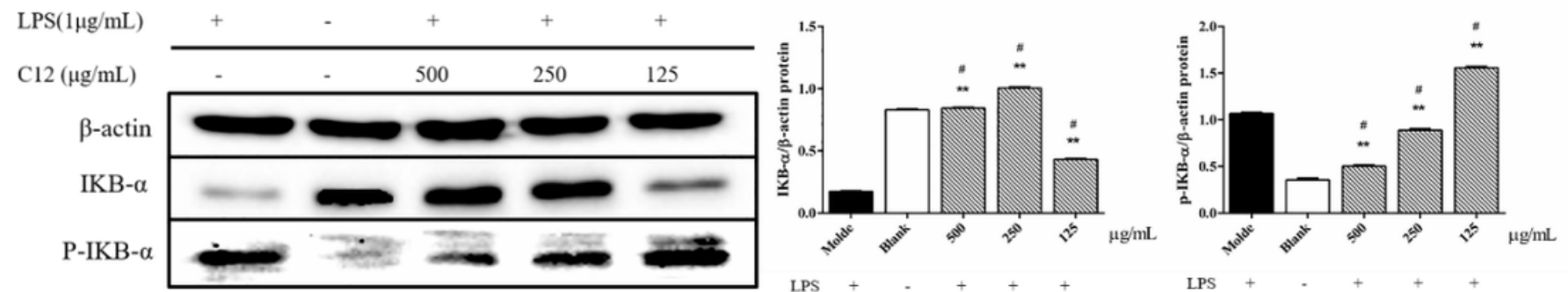

\section{Figure 7}

The effects of $\mathrm{C} 12$ on the expression of iNOS, Cox-2, and NF-K B pathway-related proteins in LPSstimulated RAW264.7 macrophages were detected. Western blot analysis of protein expression. The data represents the average value $\pm S D(n=3)$. Vs Blank, \#P<0.05 Vs the model, * $P<0.05$, * $P<0.01$ 


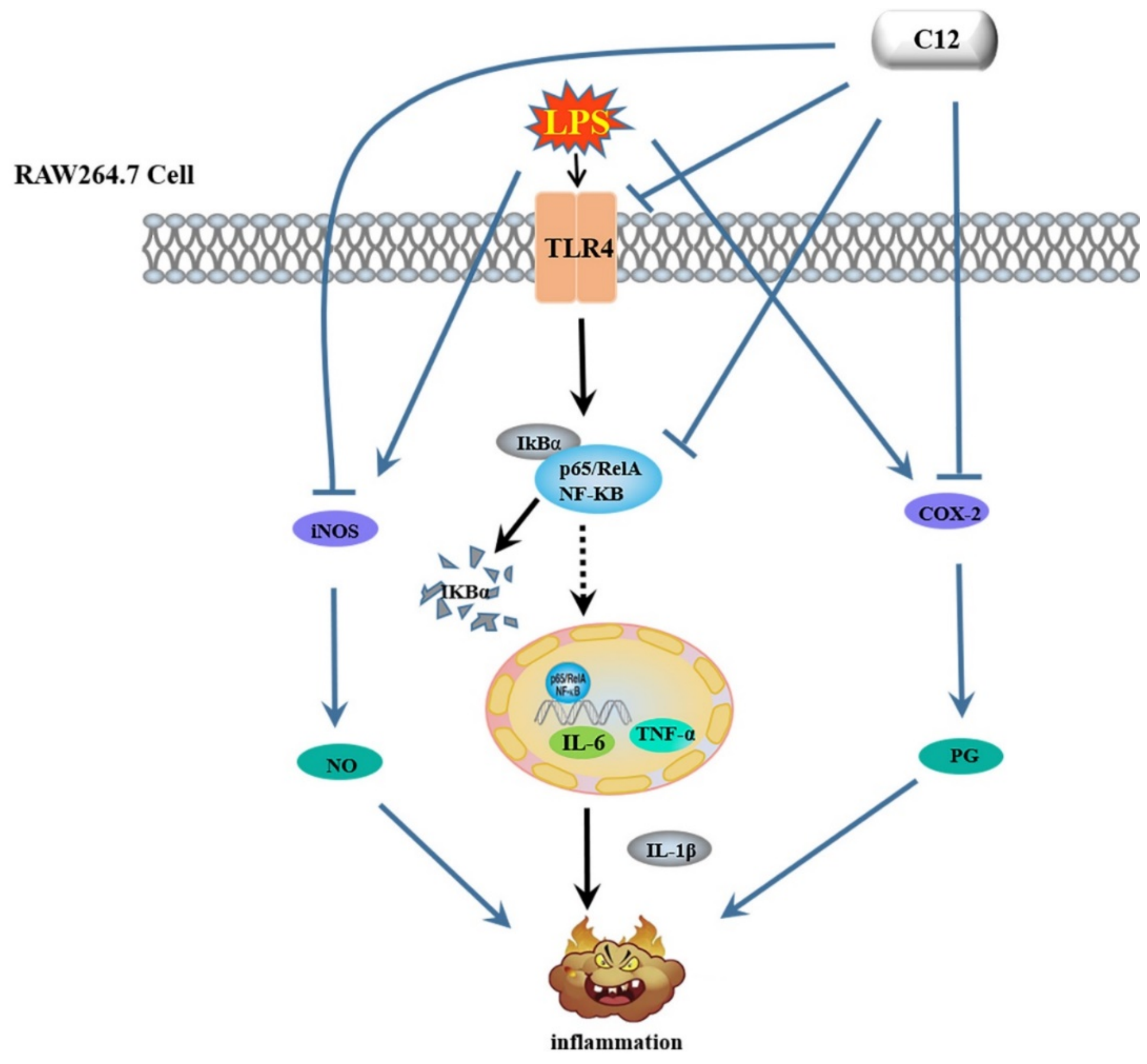

Figure 8

Overall inflammatory signaling pathway.

\section{Supplementary Files}

This is a list of supplementary files associated with this preprint. Click to download.

- SupplementaryMaterial.doc 